\title{
POTENTIAL OF NON-GOVERNMENTAL ORGANISATIONS IN SOCIAL ENTREPRENEURSHIP FROM THE PERSPECTIVE OF A REGIONAL CITY
}

\author{
Zaiga Oborenko ${ }^{1}$, Baiba Rivza ${ }^{2}$, Marga Zivitere ${ }^{3}$ \\ ${ }^{1,2}$ Faculty of Economics and Social Development, Latvia Agriculture University, \\ 18 Svetes Str., Jelgava, Latvia \\ ${ }^{3}$ Ventspils University College, 101a Inzenieru Str. Ventspils, Latvia \\ E-mails: ${ }^{2}$ zaiga.oborenko@gmail.com (corresponding author); \\ ²baiba.rivza@llu.lv; ${ }^{3}$ marga.zivitere@isma.lv
}

\begin{abstract}
Employment of people with disabilities is very important in reducing the risk of poverty, social integration and participation in society. As it is difficult for people with disabilities to integrate into the labour market, social enterprises can be considered as a new opportunity for employment and social inclusion. This study investigates opportunities for social entrepreneurship development based on non-governmental organisations from the perspective of a regional city in Latvia. The paper applies analytical study of secondary sources and in-depth interviews with representatives of non-governmental organisations. The results indicate that non-governmental organisations offer diverse potential for social entrepreneurship development, and various forms of cooperation with local authorities might be possible.
\end{abstract}

Keywords: employment of people with disabilities, social inclusion, social enterprise, community based organisation, local government.

JEL Classification: I38, L31, R23.

\section{Introduction}

The European social enterprise landscape is evolving rapidly. By linking economic and social value creation, social enterprises play a key role in building more inclusive economies and more realistic societies. They can create new jobs, be a vehicle for efficient and effective service delivery, boost citizens' participation in their local communities, and turn innovative ideas into action for the benefit of the common good. Social enterprises can only meet their full potential if an enabling environment is in place to allow them to start-up, scale-up and flourish (OECD/EU, 2017). Many European Union countries have recently addressed the social entrepreneurship support and promotion policy field with dedicated legislation or strategic frameworks. (European Commission, 2014, 2015, 2016). New social enterprise support organisations and networks are also emerging, while other already established networks are placing more importance on this issue.

The Law on Social Enterprise (Saeima, 2017) was adopted by the Parliament of Latvia on the 12th October, 2017 and it took effect on the 1st April, 2018. The Social Entrepreneurship Association of Latvia (SEAL) was established by the end of 2015. The Association serves as a national level advocacy organisation for social enterprises, representing their interests at the national and local level working together with policy and decision makers to create a well-functioning social entrepreneurship eco-system in Latvia. The organisation works closely with local municipalities and the Ministry of Welfare towards creating a support system for social enterprises on a local and national level.

Local and regional authorities have both a direct interest and an important role to play in creating favourable conditions for the social economy and social enterprises in the territories in which they operate and contributing to a response to social needs (OECD, 2010; EU, 2016).

Social enterprises can be important partners for governments, helping them meet major policy objectives such as reducing unemployment and poverty and increasing social cohesion $(\mathrm{OECD} /$ LEADS, 2013; OECD/EU, 2017). Social enterprises are longstanding agents of inclusive growth and have proved remarkably resilient in the face of economic adversity (ibid.).

Fields where social enterprises operate are diverse. One of the fields where social enterprises operate is workforce integration. Inequality and persistent unemployment for vulnerable groups in 
particular have come to the fore as priority policy issues, not only with respect to social justice but also with respect to economic growth (OECD/EU, 2017; European Commission, 2016).

Disabled people are generally the last identity group to enter the workforce and usually find jobs in low unemployment conditions. Employers do not see people with disabilities as a big potential for the workforce even if unemployment rates are low and they meet a workforce shortage. Influential disability study author, Marta Russell, carried out an analysis of the micro- and macroeconomic realities of the market economy which directly impede disabled peoples' employment and perpetuate a disabling society (Russell, 2002). For business organisations it is very important to keep high productivity, therefore, in many cases employees with disabilities are seen as an extra burden, who generate additional costs and lowers profits. Social entrepreneur, economist Muhammad Yunus, who was awarded the Nobel Peace Prize, pointed out that capitalism is interpreted too narrowly (Yunus, 2006). Alongside people who are oriented to the maximization of profit, there are another type of people who are social-objective driven and committed to make a diference to the world (ibid.). Commercial entrepreneurship focuses strictly on markets that can provide profitable opportunities, while social entrepreneurship is attracted by an unmet need, demand or market failure, i.e., the opportunity for social change (Hockerts, 2006; Pestoff \& Hulgard, 2015).

The primary aim for social enterprises is not to make a profit, but to provide innovative solutions to unsolved social problems, putting social value creation at the heart of their mission in order to improve individual and community lives and increase their well-being (OECD, 2010; European Commission, 2015). The distinction between social and commercial entrepreneurship is not dichotomous, but rather more accurately conceptualised as a continuum ranging from the purely social to the purely economic (Austin, Stevenson, \& Wei-Skillern, 2006). In general, social entrepreneurship is an integral part of Europe's diverse social market economy. Social entrepreneurship is only a small part of the social economy, which also includes inclusive and socially responsible entrepreneurship.

As it is difficult for people with disabilities to integrate into the labour market, social enterprises can be considered as a new opportunity for employment and social inclusion.

A well developed third sector is an essential component of any society (Borzaga \& Defourny,
2001). Studies stress the fact that the third sector (non-governmental organsations, non- profit sector, civic society sector) has its own specific role in Europe provided by means of a number of organisations which add value and employment (Borzaga \& Santuari, 2003; Defourny, 2001, 2014; Salamon et al., 1999, 2004; Salamon \& Sokolowski, 2016). Both experience and research demonstrate that a well-established and dynamic non-profit making sector can contribute, not only to social cohesion, but also to the efficiency and dynamics of the whole economic system (Borzaga \& Deforny, 2001).

The persistence of structural unemployment in many countries, the need to reduce the state budget deficits and to keep them at a low level, the difficulties of traditional social policies and the need for more active integration policies have naturally raised the question of how far the third sector can help to meet these challenges and perhaps take over from public authorities in some areas (Defourny, 2001). There should be pointed out that various new forms of mutual cooperation are emerging where responsibility could be shared among public and municipal authorities, commercial companies and non-governmental organisations or new social enterprises on the basis of strict criteria of both efficiency and fairness. Numerous analyses of the third sector have already demonstrated that this sector has often developed in response to needs in areas where the traditional private sector or the state were unable to provide a satisfactory solution.

The potential of non-governmental organisations to develop as social enterprises in Latvia has not been the subject of scholarly articles until now. In the context of the new Social Enterprise Law (Saeima, 2017), the actual task is to identify the sector's capacity, how many of non-governmental organisations will transform into social enterprises and how many of them will retain their status within the existing regulatory framework.

The aim of this study is to investigate opportunities for social entrepreneurship development based on non-governmental organisations from the perspective of a regional city, Ventspils in Latvia. The principal objectives of this paper are first, to find out what is the potential of community based organisations to develop into social enterprises; second, what are the forms of cooperation with local authorities and, third, what are the job opportunities for people with disabilities? In order to reach the goal and defined objectives, specific tasks were carried out: 1) theoretical background was studied, 2) legal and policy 
framework analysed, 3) content analysis of different researches done, 4) in-depth expert interviews were held.

Research hypothesis: non-governmental organisations offer diverse potential for social entrepreneurship development and new employment opportunities can be created. The following scientific research methods were employed in the present research: the monographic and descriptive methods, analysis and synthesis, induction and deduction. The novelty of this study is evaluation of interaction between community based nongovernmental organisations and local government activities in order to develop locally based social enterprises.

\section{Materials and methods}

The object of this study is Kurzeme region's city Ventspils. Ventspils is a city in northwestern Latvia, and is the sixth largest city in the country. At the beginning of 2017, Ventspils had a population of 39,286. It is situated on the Venta River and the Baltic Sea, and has an ice-free port.

A wide range of scholarly papers and scientific literature, different research and institutions' documents was studied. The design of this study was organised as follows: 1) the theoretical background of social enterprises emerging and the changing third sector was studied; 2) the position and policy of the OECD and the European Union were analysed; 3) special attention was paid to the study of scientific publications devoted to the topic of social entrepreneurship development in Latvia (Bikse, Linde, \& Rivza, 2014; Bikse \& Linde, 2016; Dobele, 2012, 2013; L. Dobele \& A. Dobele, 2014; Plotnieks, 2014); 4) different Latvian institutions' research on social entrepreneurship were studied (Cabinet, 2014; Lesinska et al., 2012; Lesinska, 2014; Lis, Wallberg, Nordström, Suvajevs, \& Ulande, 2017; Pukis, 2012); 5) legal and policy frameworks for social enterprises in Latvia were analysed; 6) a special focus was on local municipalities' interests in development of social enterprises (LARG, 2016; Lis et al., 2017); 7) the trends in the non-governmental sector were studied (Caune, Neilande, Krievina-Sutora, \& Pipike, 2016); 8) Ventspils City Council development programmes were studied and, finally; 9) content analysis of research on Ventspils city and district employment situation, within the framework of which; 10) interviews of experts from the NGO sector were conducted to find out the job creation potential in developing the social enterprise sector.

\section{Findings on the environment}

\subsection{Legal and policy framework}

The existence of appropriate legislation favours the functioning of social enterprises. The objective of the Social Enterprise Law (Saeima, 2017) is to support the improvement of society's quality of life and to promote employment for groups at risk of social exclusion, through the creation of an economic environment that supports social enterprises. According to the Law, the Ministry of Welfare is the responsible institution for developing policy planning documents and support programmes for social enterprises. The Law also gives municipalities the right to participate in establishment and operation of a social enterprise. So the aim is that the municipality takes part initially but, after three years, this company will become completely private. The new social enterprise law stipulates a number of benefits for eligible social enterprises: involvement of volunteers, certain tax reductions and access to European Union funds. Furthermore, the new law enables municipalities to create and implement their own local support instruments - reduced real estate tax, permission for social enterprises to use municipality property for free, special financial support schemes or privileged public procurement procedures for social enterprises. Additionally, state subsidies are available to enterprises employing people with disabilities.

In 2016, The Ministry of Welfare in cooperation with ALTUM, a state owned development finance institution, launched a grant programme, whereby funds from the European Social Fund are allocated to prospective social enterprises. The programme will run until 2022, and will potentially create a basis for a future long-term comprehensive support system for social enterprises.

The Public Procurement Law (2016) gives privileges to entrepreneurs and NGOs who employ people with disabilities. It is planned to include social entrepreneurs as the subjects of priviliged rights agreements.

For employers, there is a motivation to employ people with disabilities - the State Employment Agency offers projects on subsidised jobs. However, it should be emphasised that these instruments are introduced for a certain period and do not have a long-term impact on employment of disabled people in the country. Whereas, social enterprises are seen as an opportunity for people with disabilities to be employed and socially included. Possibly, in today's situation, where subsidised employment measures predominate, social 
entreprenerurship can prove to be more cost-effective and more targeted because it involves the community through socially responsible entrepreneurs and provides stable, predictable and longterm support through a regulatory framework and short-term support with special programmes (Baltijas Konsultācijas, Agile \& Co, 2017).

There is a high proportion of NGOs among employers using state subsidised jobs and, for these organszations, in the context of limited funding, it is a substantial state support. In a situation where the labour market is relatively inaccessible to people with disabilities, social entrepreneurship is seen as an alternative to creating a specially supported and protected labour market niche.

Because of interest about the NGO sector as a main potential player for social enterprise development, a regulatory framework for NGOs will be introduced. The activities of NGOs are mainly regulated by two laws - the Law on Associations and Foundations (Saeima, 2003) and the Law on Public Benefit Organisations (Saeima, 2004). According to the Law associations, foundations have the right to perform economic activity in the form of complementary activity to achieve the goals of the organisation. The analysis of NGO income positions for the year 2014 shows that the greatest share of income, $47.46 \%$, comes from the economic activities of the organisations (Caune et al., 2016). Thus, it can be concluded that, from the economic point of view, there are favourable conditions for NGOs to transform into social enterprises.

The purpose of the Public Benefit Organisations Law is to promote the public benefit activities of associations and foundations. According to the Law, a public benefit activity is an activity which provides a significant benefit to society, especially if it is directed towards charitable activities, protection of civil and human rights, development of civil society, education, science, culture and promotion of health and disease prophylaxis, support for sports, environmental protection and raising the social welfare of society, especially for low-income and socially disadvantaged groups.

One of the most significant events in the legal field of the NGO sector in 2015 has been the promulgation of the Law on Voluntary Work (Saeima, 2015). The Law serves as the basis for several legal enactments, which will protect volunteers the same way as every other person in labour relations is protected.
Non-governmental organisations operating in Latvia have a relatively favourable legal environment. What will be the choice of each NGO becoming a social enterprise or maintaining its current legal status, - depends on the long-term vision each of them see.

\subsection{Social enterprises sector in development}

Social entrepreneurship is a new phenomenon in the Baltic States, in the stage of development. Social business organisations in the Baltic States are basically small enterprises and operate at a local level (Dobele, 2013; Moskvina, 2013; Raišiene \& Urmanavičiene, 2017; Shina \& Titko, 2017). It is difficult for them to make decisions about growth. The biggest challenge for these organisations is how to sustain economically their operations and remain on the market.The development of a social economy faces surprisingly similar barriers, while the progress of sector development is different from country to country (Pomykol, Zglinicka, \& Masłowski, 2016; Shina \& Titko, 2017).

There are no official statistics on the size of the sector and little research has been done that would clearly specify the characteristics of the industry. Calculations are complicated by the current variability of legal forms adopted by social entrepreneurs. However, it is estimated that around 120-180 social enterprises operate in Latvia. One report in 2014 surveyed 1.296 commercial entities and only $3 \%$ were identified as social enterprises, amounting to approximately thirtynine enterprises (Cabinet, 2014). The Association of Social Entrepreneurship in Latvia currently counts forty-six existing and "soon-to-be" social enterprises among its members (Lis et al., 2017). There are two options to establish social enterprise. Figure 1 shows the changes in the form of economic activity in the case of determining the status of a social enterprise.

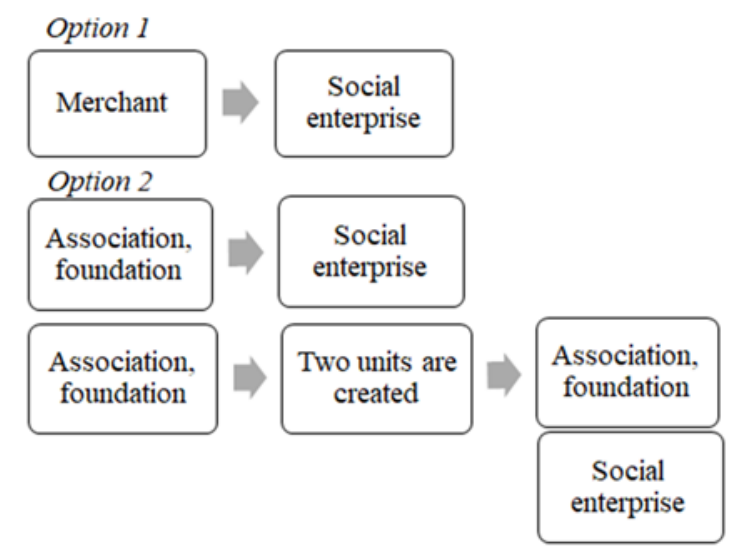

Figure 1. Scenarios of changes in the forms of economic activity (source: Cabinet, 2014) 
The enterprises operate in various sectors including, but not limited to, social services, production of goods, health services (including prevention), charity shops, environmental protection, cultural diversity and heritage, education, work integration, consulting, information and communications (web page of SEAL; SEAL, 2017). Similarly, the social enterprises work with a number of different socially vulnerable groups: senior citizens, children and youth, parents and teachers, people with disabilities, single mothers, former inmates and their families.

To protect vulnerable members of society improving further the effectiveness of social protection systems and implementing active inclusion strategies encompassing inclusive labour market measures, adequate income support and access to quality services, should be implemented. The persistence of structural unemployment, the limitations of traditional active labour market policy measures and the need for more innovative measures for social inclusion, cause a demand for new integrational solutions combining social and economic activities and values (Moskvina, 2013).

Social enterprises appear to be engaged in different activities. However, it is possible to break down these activities into two main fields: work-integration and social and community care services provision. Work-integration social enterprises are basically presented in all European countries (Borzaga \& Defourney, 2001).

From experiences in other countries, community enterprises are a specific category of social enterprise that involve local people with local knowledge in the creation and management of sustainable, non-profit making enterprises that are accountable to their local community (Haugh, 2006). Although the employment effect of social enterprises and community development initiatives remains small, their social impact - for example, assisting the excluded to become integrated into society and creating a non-market mechanism for meeting local needs - is of equal, if not greater, importance (ibid.). Social enterprises are created by people who are closely linked with the community they intend to serve.

Social enterprises exist to maximise positive social impact and ethical practice enables this. (Mason, Kirkbride, \& Bryde, 2007). Social entrepreneurship and enterprise models might be different (Alter, 2006, 2007; Brouard \& Larivet, 2011; Defourny \& Nyssens, 2010, 2016; Grassl, 2012; Szegedi, Gyula Fülö, \& Ádám Bereczk, 2016). What kind of social enterprise will be created in Latvia is the topic for other research.

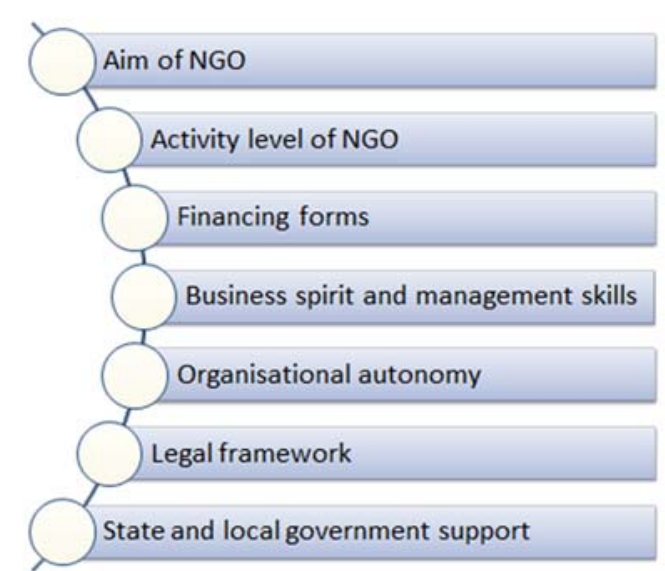

Figure 2. Factors influencing development of social enterprises (source: authors' compilation)

As was investigated in this study, many impact factors have to be considered (see Figure 2) when a social enterprise is formed such as: the purpose and mission of the organisation, the activity level of the organisation in society, the social impact the organisation's activities, how the organisation gets finance, how new legal forms will change the autonomy level, is the "new born entrepreneur" business minded and will the company be sustainable from the point of financial resources?

\subsection{Changes in the non-governmental sector}

Research on the non-governmental sector is important from the perspective of developing a social entrepreneurship, as a part of the organisation carries out economic activities and employs staff. The question is, how many NGOs are planning to become social enterprises that will create new jobs and employ socially disadvantaged people? The statistics of NGOs' by different regions of Latvia (see Table 1) show that the third sector has grown significantly in the last few years.

In Kurzeme (the region of this paper's interest), out of two thousand six hundred and seventy-five non-governmental organisations, two hundred and fifty-eight different associations and foundations operate in Ventspils (Caune et al., 2016). Ventspils Regional NGO Support Centre unites twenty-one member organizations and four individuals. Despite the large volume of organisations, the most active ones are considered six organisations acting in Ventspils: Zelsirdibas maja (Charity House), Gimdins (Glove), Spekuguns (Power fire), Atvertas durvis (Open Doors), Sparni (Wings), Pasparne (Under wings). 
Table 1. NGO dynamics in absolute numbers by regions (source: Caune et al., 2016)

\begin{tabular}{|l|c|c|c|}
\hline $\begin{array}{c}\text { Regions of } \\
\text { Latvia }\end{array}$ & $\begin{array}{c}\text { End of } \\
2013\end{array}$ & $\begin{array}{c}\text { Beginning } \\
\text { of } 2016\end{array}$ & Growth \\
\hline Riga & 7813 & 12539 & +4726 \\
\hline Kurzeme & 2258 & 2675 & +417 \\
\hline Latgale & 1585 & 1988 & +403 \\
\hline Zemgale & 1441 & 1820 & +379 \\
\hline Vidzeme & 1498 & 1601 & +103 \\
\hline Latvia total & 14595 & 20623 & +6028 \\
\hline
\end{tabular}

As for NGO sector trends, one of the phenomena noticed in the sector over the last years has been the number of NGOs "living" only from the income of increasing economic activity (Caune et al., 2016). An increasing number of NGOs, in the traditional non-profit sector, are starting to become more entrepreneurial and develop commercial activity as a means to secure sustainability of their operations. Conditions have changed, limiting access to funding, especially grant funding from international philanthropic foundations. Hence this is considered to be one of the main reasons for the reorganisation of some NGOs.

Studies show that, as the most significant collaborative partners, non-governmental organisations see other non-governmental organisations, which are located in the same town and municipality or work in a similar field, and municipality institutions. (Caune et al., 2016).

When looking for possible scenarios for the development of social enterprises, the role of the municipality that can use its administrative capacity and the budget for implementing various activities, should be emphasised. The possibilities of social entrepreneurship can be found where it is possible to form a positive result of economic activity.

\subsection{The municipality as a player in the social enterprise support system}

Whether social entrepreneurship will become more important and strong, impetus to the development of the social economy sector depends largely on the local authorities' attitudes and actions. Creating meaningful, productive and long lasting partnerships and cooperation modes with local municipalities is both a challenge and an opportunity. Since the social issues, problems and challenges that social enterprises and municipalities are attempting to tackle are, in many cases, similar or the same, it would seem only logical that social enterprises and municipalities could and should be allies and partners in their work. In reality, however, it is not that simple - social enterprises and municipalities often struggle to find common ground, and the road to an effective and productive partnership turns out to be more difficult and time consuming than anticipated (Lis et al., 2017). While there is no one specific role municipalities undertake in relation to social enterprises, there are many ways in which municipalities can help and support their activities (see Figure 3).

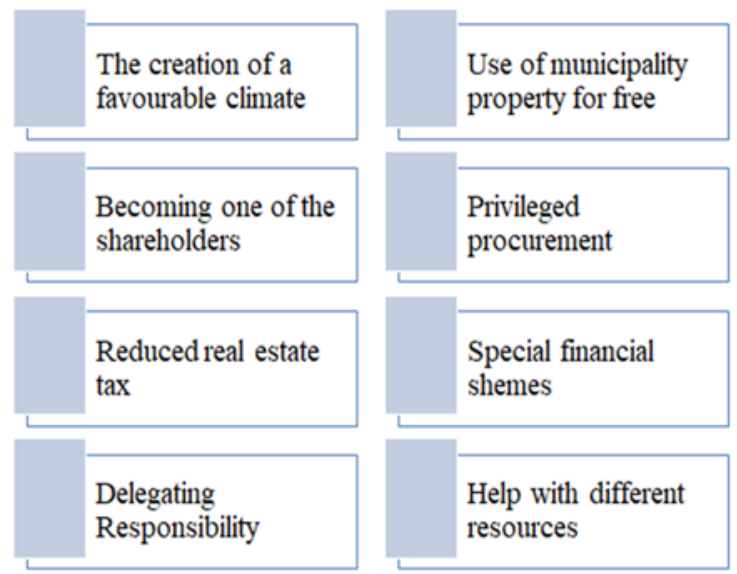

Figure 3. The role of local government (source: authors' compilation)

As social enterprises directly improve the quality of social life, fulfilling a function traditionally assigned to public bodies, municipalities may procure their services. They may organise open competitions or, in the absence of competition, simply delegate the responsibility to a social enterprise. While procurement of social services generally functions well and has been developing in a consistent manner over the past twenty years, procurement in other areas, like goods or other products, is not as developed. There is enormous room for growth but, currently, a lack of awareness of best practices impedes this development (Lis et al., 2017). Municipal funding can also be released in the form of grants earmarked for specific target groups and their integration into the labour market.

The new Social Enterprise Law also enables municipalities to create their own social enterprises as co-owners, under strict and limited circumstances: public bodies (alone or together with other public bodies) cannot hold majority shares in the enterprise; the municipality co-owned enterprises can only operate in the field of work integration. This particular norm is in effect only until 2021. The form of cooperation depends on 
the length of partnership, the professional competence of municipality officials and their general interest in the services provided by the social enterprise. A significant factor is the willingness of the municipality to involve social enterprises in decision-making and policy formation.

\subsection{Employment of people with disabilities}

One of the most important problems related to employment is the inclusion of socially vulnerable groups in the labour market. Ventspils Municipality has been planning to carry out various social inclusion measures (Ventspils City Council, 2013, 2016), including promoting employment of vulnerable groups, providing services for people with disabilities and adapting the environment to the needs of people with disabilities.

In the survey held in April, 2017, 18\% of entrepreneurs in Ventspils city and county indicated that they have hired people with disabilities during the last two years. People with disabilities are mostly employed by companies with more than two hundred and fifty employees, followed by companies with a staff of fifty - two hundred and forty-nine (Ventspils University College, 2017).

The greatest employers' response to the implementation of employment measures is the summer employment of pupils and the creation of subsidised jobs for the disabled unemployed. Engagement in the implementation of the measures depends on both the conditions of the measures and the grant provided by the state (ibid.).

As unemployment indicators show positive trends, the amount of unemployed people with disabilities are relatively high (see Table 2).

Non-governmental organisations are involved in the implementation of the Youth Guarantee Measures activities. The greatest response is to the measure Development of the skills needed for work in the non-governmental sector and the creation of subsidised jobs through which young people gain work experience. State supported subsidised employment measures solve temporary inclusion to the labour market. There are very few people with disabilities remaining in regular employment after the end of subsidised jobs, after which they again receive unemployed status. Most people with disabilities during the initial period of unemployment are looking for a job in line with their professional qualifications and competences, skills and health, but do not want to work full-time. The employer, in turn, needs an employee with full-time working hours. As the study shows, usually people with disabilities are employed in low-skilled jobs (Ventspils University College, 2017).

Table 2. Unemployment rates and the proportion of unemployed people with disabilities in the regions of Latvia (source: The State Employment Agency, Central Statistical Bureau of Latvia, February 2018, compiled by authors)

\begin{tabular}{|l|c|c|}
\hline $\begin{array}{c}\text { Statistical } \\
\text { regions }\end{array}$ & $\begin{array}{c}\text { Unemploy- } \\
\text { ment rate } \\
\%\end{array}$ & $\begin{array}{c}\text { Unemployed PwD* } \\
\text { from total unem- } \\
\text { ployed in \% }\end{array}$ \\
\hline Riga & 4.1 & 8.3 \\
\hline Pieriga & 4.4 & 9.4 \\
\hline Kurzeme & 8.1 & 14.3 \\
\hline Ventspils & 4.8 & 13.6 \\
\hline Latgale & 16.0 & 17.7 \\
\hline Vidzeme & 7.8 & 14.2 \\
\hline Zemgale & 6.9 & 10.3 \\
\hline Total Latvia & 7.1 & 13.0 \\
\hline
\end{tabular}

*People with disabilities.

In the economic section of the Ventspils City Development Programme, there are planned comprehensive tasks for the promotion of employment, providing special measures for securing the workforce responding to the business demands (Ventspils City Council, 2013, 2016). Trends in the labour market of Ventspils also indicate that the labour force is not willing to work at the low wages offered to jobseekers. At the same time, these jobseekers lack the skills and the mobility to fill vacant qualified jobs. Effective use of human resources is hampered by the mismatch between the labour supply and demand.

\section{Results and dicussions}

\subsection{Findings of interviews}

The main criteria for the respondents' selection for expert interviews were representation of organisations that have solid experience in the field of NGO and could develop social enterprises. For in-depth interviews, four of the most experienced professionals from Ventspils non-governmental organisations were selected: 1) the head of Ventspils Regional NGO Support centre and the director of the Crisis centere for families with children Pasparne (Under the Wing); 2) the head 
of the foundation, support centre for families and children with special needs Cimdins (Glove); 3) the head of the foundation, alternative care centre Zelsirdibas maja (Charity House) and 4) Ventspils county women's association Sparni (Wings), souvenir shop Ventinpurlad (Trousseau Chest) manager. Interviews were held from the 16th to the 18th May, 2017.

The research was carried out using semistructured interviews. Three main questions of the research were formulated as follows:

1) What are the current organisation's activities and how is the organisation financed?;

2) How does cooperation with the Ventspils City Council take place and how is it valued?;

3) What opportunities are seen for their organisation to develop as a social enterprise by creating new jobs for socially vulnerable groups of the population?

Expert 1. Crisis centre for Families with Children Pasparne, established in 2003, is an aid institution, 24 hours round the clock provision, providing social, psychological, legal, pedagogical, informative and educational assistance to: 1) children who have suffered from illegal activities; 2) women who have suffered from violence; 3) people in crisis situations; 4) adult people (women and men) who have suffered from violence. The Centre provides assistance on the basis of rehabilitation programmes helping victims of violence and their families for a period of one to six months. The Crisis Centre offers shelter, food, day care for the child and his family members in a crisis situation; individual consultations with the specialists of the Centre; information on available assistance and services in Ventspils and elsewhere in Latvia. At the Centre about two hundred clients stay during the year. They stay there for an average of one month, sometimes longer. Clients are from disadvantaged families, rooms must be cleaned and repaired after their stay, it requires additional resources on a regular basis.

The collaboration with Ventspils City Council is positively evaluated. The Centre sells its services to the Ventspils municipality through procurement, there is a contract on the provision of services. The Centre manages the Children's Fund, providing assistance to disadvantaged mothers with children and there is a delegation from the Ministry of Welfare.

The Centre has an agreement with the Orphan's Court on vocational training for custodians and foster families. The Centre implements
$90 \%$ of national programmes in its activities. The crisis centre employs sixteen people, twelve are full-time and three or four are recruited as volunteers. The Crisis Centre also has cooperation with the probation service, employing volunteers.

The Centre has the idea of setting up a bakery in the same building as the Centre. However, it is clear that the aim of this bakery will not be to create new jobs, but to employ the socially excluded people who are clients of the Crisis Centre.The opportunity to develop as a social enterprise is being considered, however, it is being seen as a complex issue.

Expert 2. The Centre Cimdins, established in 2010, is run with the intention of providing needed support for disabled children and their families. Rehabilitation, social inclusion, education, leisure activities, employment and other activities are carried out according to each individual need. The Support Centre was established in the framework of the project Development of Multifunctional Support Centre for Children with Special Needs implemented by the Latvian Children's Fund and the Ventspils City Council. The project is designed to provide access to social and medical rehabilitation services for children and young people with special needs and their families. In the Centre children and young people with special needs can participate in music therapy, bobot gymnastics and creative workshops.

The Center employs ten specialists: a social worker, a psychologist, a speech therapist, a social rehabilitator, a physician, Montessori development classes, an early correctional teacher specialist and five volunteers. The Centres operations are supported by the Ventspils City Council and donations. Innovative methodlogical materials for the social integration of the target group in the community were developed by Cimdins together with the Ventspils County Social Services. Consequently, further social integration measures for children and young people with disabilities are planned in accordance with the developed methodology. The material is innovative in terms of content and form, as the social workers currently have no equivalent material to work with the target group. In 2017 Cimdins implemented the project We are, we can! financed by the Latvian state budget NGO Fund. The aim of the project is to strengthen the capacity of the Centre to promote the involvement of children and young people with disabilities in civil society activities in Ventspils city 
and the county, providing social services that promote their integration and participation in civil society processes.

To develop as a social enterprise is not considered yet, because the Centre is more focused on providing social services. However, the organisation is struggling for funding. Products of the workshop, such as mats, could be sold in order to earn some revenues, but this is not the aim of the Centre. This interview was held in May, 2017, now Cimdins is a member of Social Entrepreneurship Association of Latvia.

Expert 3. Alternative Care Centre Zelsirdibas maja was founded in 1995, in 2001 the Centre was registered as a non-governmental organisation, in 2005 it was registered as a foundation and in 2006 the Centre obtained Public Benefit Organisation status. In 2009 the Centre was registered as a social service provider's group house (apartment) in the Register of Social Services of the Ministry of Welfare. Zelsirdibas maja is an alternative to specialised state social care centres (psychoneurological internships). Young people with mental disabilities live in, close to the family environment and acquire social and work skills. More than one hundred young people have lived in the Cenrer. No more than sixteen young people live in the fund's home at the same time. The fund manages three properties - houses and land near Ventspils where young people live, learn to adapt to their everyday life and learn work skills.

The idea of an opportunity to develop entrepreneurship under the umbrella of the foundation was born after several young people of the house became professional cooks, but were not able to find a job. The "Closed Catering" company was set up, employing nine young people. Consequently, boys and girls not only upgraded their knowledge of the profession they acquired, but also acquired a job record, which in turn enabled them to receive a pension for a disabled person, which is much higher than the social benefit for a disabled child. The productivity of young people employed is low, and the costs associated with maintaining this type of business are high.

When assessing the organisation's performance, it should be concluded that the Centre is an example of a social enterprise, in which the social problem is solved with economic activities - in a direct and indirect way. Primarily, the foundation is an organisation that is not profitoriented, but aims at solving social problems teaching social and work skills to children and young people with intellectual and mental disabilities. On the other hand, economic activity is an instrument or a way to provide young people with the opportunity to acquire work skills, as well as to generate addional funding for the operation of the Centre. The Centre has been financially supported by several local county companies as well as private individuals. The municipality grants support the Centre by paying the utility bills. However, more support is expected from the Ventspils City Council. Without specific state and local government support, the Centre's business activities are subject to various risks, one of which is - the inability to pay all payments. Unfortunately, the cafe is closed now, young people have lost their jobs and there is only a tiny chance that they will ever be able to find other gainful jobs.

Zelsirdibas maja addresses the employment and integration of people with mental disabilities into society. The inclusion of people with severe disabilities and mental disorders into the labour market is an important field of activity that the Ministry of Welfare has included in its plans of activities as one of the tasks in line with the policy of the European Union.

Expert 4. Ventspils County Women's Association Sparni (Wings) was established in 2001, scope 1) co-ordination of activities of Ventspils city and county women, provision of information circulation, training, education; 2) preservation of the cultural heritage, sale of art and crafts in salon Ventinpurlad. Target groups are women's associations, foundations and interest groups, craftsmen, artists, souvenir producers. The shop is a department of the organisation Sparni, which sells various souvenirs and handicrafts of two hundred and fifty craftsmen. Shopping has a seasonal nature related to tourism. The store participates in various events organised by the city organisers in which Ventipurlad markets their products.

Souvenir Salon has been operating for almost ten years. Its chairman is also Deputy Chairman of the Board of the women's organisation Sparni. She is in charge of organising seminars and meetings, as well as engaging in drafting projects to raise funds for the organisation of the Centre and activities involving Sparni representatives. 
Table 3. Summary of expert interviews (source: compiled according to authors' interviews)

\begin{tabular}{|c|c|c|c|c|}
\hline Question & $\begin{array}{c}\text { Expert No } 1 \\
\text { Pasparne }\end{array}$ & $\begin{array}{c}\text { Expert No } 2 \\
\text { Cimdins }\end{array}$ & $\begin{array}{c}\text { Expert No } 3 \\
\text { Zelsirdibas maja }\end{array}$ & $\begin{array}{c}\text { Expert No } 4 \\
\text { Sparni }\end{array}$ \\
\hline Activities & $\begin{array}{l}\text { Crisis centre for } \\
\text { young mothers with } \\
\text { children. } \\
\text { Centre implements } \\
90 \% \text { of national } \\
\text { programmes }\end{array}$ & $\begin{array}{l}\text { Social services for } \\
\text { children with disa- } \\
\text { bilities }\end{array}$ & $\begin{array}{l}\text { Promotes employ- } \\
\text { ment and integra- } \\
\text { tion into society for } \\
\text { young people with } \\
\text { mental disorders. } \\
\text { Farmstead }\end{array}$ & $\begin{array}{l}\text { Women's organisa- } \\
\text { tion Education and } \\
\text { training for women. } \\
\text { Preservation of the } \\
\text { cultural heritage, } \\
\text { craftsmanship salon }\end{array}$ \\
\hline People employed & $\begin{array}{l}12-\text { full-time, } 3-4 \\
\text { volunteers }\end{array}$ & $\begin{array}{l}10-\text { full time, } \\
5-\text { volunteers }\end{array}$ & $\begin{array}{l}3 \text { - full time, } 9 \text { with } \\
\text { mental disabilities }\end{array}$ & $\begin{array}{l}1 \text { - full time, } \\
4 \text { from youth pro- } \\
\text { gramme- subsi- } \\
\text { dised jobs }\end{array}$ \\
\hline Forms of financing & $\begin{array}{l}\text { Sells social services } \\
\text { to Ventspils City } \\
\text { Council and state } \\
\text { institutions }\end{array}$ & $\begin{array}{l}\text { Support from } \\
\text { Ventspils City } \\
\text { Council, State sup- } \\
\text { port, EU funds, do- } \\
\text { nations }\end{array}$ & $\begin{array}{l}\text { Revenue from eco- } \\
\text { nomic activities, } \\
\text { Support from } \\
\text { Ventspils City } \\
\text { Council, State sup- } \\
\text { port, EU projects, } \\
\text { donations }\end{array}$ & $\begin{array}{l}\text { Sale of craftsman- } \\
\text { ship works in the } \\
\text { salon. } \\
\text { Revenues from ed- } \\
\text { ucation and train- } \\
\text { ing. } \\
\text { Project grants }\end{array}$ \\
\hline $\begin{array}{l}\text { Cooperation with } \\
\text { city council }\end{array}$ & $\begin{array}{l}\text { Very close, de- } \\
\text { pending on the city } \\
\text { council }\end{array}$ & $\begin{array}{l}\text { Projects with Min- } \\
\text { istry of Welfare, } \\
\text { Latvian Children's } \\
\text { fund and Ventspils } \\
\text { city council, dona- } \\
\text { tions. }\end{array}$ & $\begin{array}{l}\text { Projects with state } \\
\text { and EU support, } \\
\text { expect more sup- } \\
\text { port from Ventspils } \\
\text { Council }\end{array}$ & $\begin{array}{l}\text { Good cooperation } \\
\text { with city council } \\
\text { and State Employ- } \\
\text { ment agency }\end{array}$ \\
\hline $\begin{array}{l}\text { Possible future } \\
\text { development } \\
\text { scenarios }\end{array}$ & $\begin{array}{l}\text { Could develop as a } \\
\text { social enterprise } \\
\text { with strong City } \\
\text { Council support or } \\
\text { participation. }\end{array}$ & $\begin{array}{l}\text { Strong focus on so- } \\
\text { cial services, mind- } \\
\text { ful of NGO mis- } \\
\text { sion. Could } \\
\text { develop economic } \\
\text { activities in order } \\
\text { to get additional } \\
\text { revenue. } \\
\text { Member of SEAL* }\end{array}$ & $\begin{array}{l}\text { This organisation is } \\
\text { practically acting as } \\
\text { a social enterprise. } \\
\text { Should change the } \\
\text { status and be regis- } \\
\text { tered as a social en- } \\
\text { terprise. }\end{array}$ & $\begin{array}{l}\text { Management do } \\
\text { not see any reason } \\
\text { to change the sta- } \\
\text { tus, therefore, will } \\
\text { remain as an NGO } \\
\text { having economic } \\
\text { activities }\end{array}$ \\
\hline
\end{tabular}

*Social Entrepreneurship Association of Latvia.

The shop has only one person employed. The rest of the human resources are provided through two programmes of the State Employment Agency: subsidised workplaces for young people and pupils during the summer holidays. Typically, a youth programme employs four people for six months, then personnel changes. In addition to the States Employment Agency programme, working with pupils during the summer holidays, there is also good cooperation with Ventspils City Council. The manager is very satisfied both with the cooperation with the State Employment Agency and with Ventspils City Council.

The opportunity to develop as a social enterprise is not considered by the manager, because there is no such need.

\subsection{Summary of interviews}

Looking at Table 3 , summarising the results of the interviews, it should be pointed out that all the organisations make positive impact on people's lives in the community in various ways - taking care of disadvantaged families with children, providing needed support for children with disabilities and their families, taking care of young people with mental disorders, or supporting community women.With quite a small amount of resources, but with extremely large commitment to their missions, these NGOs make significant social impact on local community life.

It should be emphasised that the municipality needs to think more about supporting all NGOs, as they are doing important social work helping to integrate into society various vulnerable groups of the population. Non-governmental organisations 
are small in size as to human resources and their activities will not affect employment in Ventspils city and county.

Whatever the legal status chosen by the organisation, it has to be concluded that all these organisations carry out important and significant social work for society and serve the local community.

\section{Conclusions}

1. Social entrepreneurship and social enterprises play a significant role in the social economy as OECD and EU studies prove.

2. New Social Enterprise Law has been introduced in Latvia in 2017 to support the improvement of society's quality of life and to promote employment for groups at risk of social exclusion, through the creation of an economic environment that supports social enterprises. The Social Entrepreneurship Association of Latvia was established at the end of 2015. The Association serves as a national level advocacy organisation for social enterprises, representing their interests.

3 . The non-governmental sector has undergone significant changes over recent years in Latvia, which has created favourable grounds for the development of social enterprises.

4. Although support for social enterprises development has been intended in programmes of local municipalities, there is uncertainty how this will be carried out.

5. The participation of NGOs in entrepreneurship so far has been successfully solving different social problems in local communities.

6 . The social enterprise sector is at the early development stage, new forms of cooperation with local authorities are being sought. To a large extent, subjective factors will play a major role as the study shows. Although cooperation with the city municipality has been evaluated, quite good, local non-governmental organisations expect more support from the city municipality.

7. As expert interviews show, organisations are struggling for financing in various ways - either by selling their services to the municipality, or by attracting municipality, state or EU grants, donations and carrying out economic activities.

8. Initially, a relatively small number of Ventspils city NGOs could become social enterprises. Organisations are cautious about the status of a social enterprise because of the uncertainty about the kind of benefits it could bring. It would be convenient for one part of the organisations to maintain the existing legal status.
9. Organisations will continue to provide social value for the local community, working closely with the municipality, whether in the legal form of an association/foundation or as a social enterprise, but it is quite clear that new job places for vulnerable people groups could be created at very little amount and it will not affect employment in the near future.

Social entrepreneurship is a new field of economic activity in Latvia; the Law on Social Enterprise came into force only on April 1, 2018. Nongovernmental organisations are considered as the main potential for the development of social enterprises, but it should be noted that the organisations in this sector lack business administration skills and entrepreneurial spirit. Through a comprehensive analysis of data, it has to be concluded that the development of social enterprises in the rural areas of Latvia depend on good cooperation with local authorities and the support of municipalities, because they hold significant administrative, material and financial resources.

\section{Acknowledgements}

The paper was financially supported by the Latvia National Research programme EKOSOC-LV.

The authors wish to thank Ventspils City Council and Ventspils University College for providing support in the research Reasons for the unemployment of Ventspils city and county residents and proposals for improving the situation.

\section{Disclosure Statement}

The authors declare that they do not have any competing financial, professional or personal interests from other parties.

\section{References}

Alter, S. K. (2006). Social enterprise models and their mission and money relationships. In A. Nicholls (Ed.), Social Entrepreneurship: New models of sustainable social change (Chap. 10, pp. 205-232). Oxford: Oxford University Press.

Alter, S. K. (2007). Social enterprise typology. Virtue Ventures LLC.

Austin, J., Stevenson, H., \& Wei-Skillern, J. (2006). Social and commercial entrepreneurship: Same, different, or both. Entrepreneurship: Theory \& Practice, 30(1), 122.

https://doi.org/10.1111/j.1540-6520.2006. 00107.x

Baltijas Konsultācijas, Agile \& Co. (2017). Pētījums par starptautisko praksi personu ar invaliditati atbalsta sistēmu jomā (Study on international practice in the field of support systems for people with disabilities). Riga, Ministry of Welfare. 
Bikse, V., \& Linde, N. (2016). Criteria for identification and evaluation of social enterprise. Academic Proceedings of LChrA-, 4, 265-281.

Bikse, V., Linde, N., \& Rivza, B. (2014). Possibilities of Development Social Enterprises in Latvia. In SGEM Conference on Political Sciences, Law, Finance, Economics \& Tourism. Conference Proceedings (Vol. III, pp. 399-409). Albena, Bulgaria.

https://doi.org/10.5593/sgemsocial2014/B23/ S7.051

Borzaga, C., \& Defourny, J. (2001). The emergence of Social Enterprise. London: Routledge.

Borzaga, C., \& Santuari, A. (2003). New trends in the nonprofit sector in Europe: The emergence of social entrepreneurship. In OECD, The non-profit sector in a changing economy (Chap. 1, pp. 31-56). Paris: OECD.

Brouard, F., \& Larivet, S. (2011). Social entreprises: Definitions and boundaries. In Conférence of Association for Nonprofit and Social Economy Research ANSER, 1-3 June 2011. Fredericton. University of New Brunswick.

Cabinet of Ministers (Cabinet). (2014). The concept of social entrepreneuship development opportunities in Latvia. Retrieved from http://www.lm.gov.lv/upload/aktualitates/null/lmkonc_271014_su_1_1807.pdf

Caune, E., Neilande, J., Krievina-Sutora, B., \& Pipike, R. (2016). The review of the NGO sector in Latvia. 2015. Civic Alliance - Latvia. Retrieved from http://www.nvo.lv/lv/news/ page/ petijumi-31/

Defourny, J. (2001). From third sector to social enterprise. In C. Borzaga, \& J. Defourny (Eds), The emergence of social enterprise (pp. 1-18). London and New York, Routledge.

Defourny, J. (2014). From third sector to social enterprise: a European research trajectory. In J. Defourny, L. Hulgård, \& V. Pestoff (Eds.), Social enterprise and the third sector (pp. 17-41). London and New York: Routledge.

Defourny, J., \& Nyssens, M. (2010). Conceptions of social enterprise and social entrepreneurship in Europe and the United States: Convergences and divergences. Journal of Social Entrepreneurship, 1(1), 32-53. https://doi.org/10.1080/19420670903442053

Defourny, J., \& Nyssens, M. (2016). Fundamentals for an international typology of social enterprise models. ICSEM Working Papers, No. 33. Liege: The International Comparative Social Enterprise Models (ICSEM) Project.

Dobele, L. (2012). Social entrepreneurship paradigm and its assessment in Latvia. Economic Science for Rural Development, 27, 55-63.

Dobele, L. (2013). Social entrepreneurship development possibilities in Latvia: Summary ot the Doctoral thesis. Latvia University of Agriculture.

Dobele, L., \& Dobele, A. (2014). Economic gains from social entrepreneurship development in Latvia. Regional Formation and Development Studies, 14(3), 30-39. https://doi.org/10.15181/rfds.v14i3.861

European Commission. (2014). A map of social enterprises and their eco-systems in Europe. Luxembourg: Publications Office of the European Union,

European Commission. (2015). A map of social enterprises and their eco-systems in Europe. Synthesis Report. Luxembourg: Publications Office of the European Union.
European Commission. (2016). Social enterprises and the social economy going forward. A call for action from the Commission Expert Group on Social Entrepreneurship (GECES). Retrieved from http:// ec.europa.eu/growth/sectors/social-economy/enterprises/ expert-groups_en

European Union/OECD. (2016). Policy Brief on Scaling the Impact of Social Enterprises. Policies for social entrepreneurship.

Eurpean Commission. (2018). Social enterprises. Retrieved from http://ec.europa.eu/growth/sectors/social-economy/enterprises_en

Grassl, W. (2012). Business models of social enterprise: A design approach to hybridity. ACRN Journal of Entrepreneurship Perspectives, 1 (1 Feb.), 37-60.

Haugh, H. (2006). Social enterprise: beyond economic outcomes and individual returns. In J. Mair, J. Robinson, \& K. Hockerts (Eds), Social Entrepreneurship (Chap. 12). New York: Palgrave Macmillan. https://doi.org/10.1057/9780230625655_12

Hockerts, K. (2006). Entrepreneurial opportunity in social purpose business ventures. In J. Mair, J. Robinson, \& K. Hockerts (Eds), Social Entrepreneurship (Chap. 10). New York: Palgrave Macmillan. https://doi.org/10.1057/9780230625655_10

Latvian Association of Local and Regional Governments (LALRG). (2016). Scientific Research: Social entrepreneurship opportunities for municipality and possibilities of using private social enterprises for local government purposes.

Lesinska, A. (2014). Sociālie uznēmumi- nevalstiskās organizācijas Latvijā [Social enterprises - non governmental organizations in Latvia]. Riga: Providus.

Lesinska, A., Litvins, G., Pipike, R., Simanska, I., Kupics, O., \& Busevica, K. (2012). Latvija cel̦ā uz sociālo uzñemējdarbìbu [Latvia on the way to social entrepreneurship]. Riga: Latvian Civic Aliance, Providus.

Lis, A., Wallberg, N., Nordström, T., Suvajevs, A., \& Ulande, M. (2017). Social enterprises and municipalities: Cooperation, partnerships \& synergies. An analytical review of existing and possible cooperation and partnerships between social enterprises and municipalities in Latvia, Belarus and Sweden. Riga: Social Entrepreneurship Association of Latvia.

Mason, C., Kirkbride, J., \& Bryde, D. (2007). From stakeholders to institutions: the changing face of social enterprise governance theory. Management Decision, 45(2), 284-301. https://doi.org/10.1108/00251740710727296

Moskvina, J. (2013). Social enterprises as a tool of social and economic policy. Entrepreneurship and Sustainability Issues, 1(1), 45-54. https://doi.org/10.9770/jesi.2013.1.1(5)

OECD. (2010). Social Entrepreneurship and Social Innovation. In OECD. SMEs, Entrepreneurship and Innovation (Chap. 5). OECD Publishing. https://doi.org/10.1787/9789264080355-50-en

OECD/LEED. (2013). Job creation trough the social economy and social entrepreneurship. OECD Publishing.

OECD/European Union. (2017). Boosting social enterprise development: Good practice compendium. Paris: OECD Publishing.

Pestoff, V., \& Hulgard, L. (2015). Participatory governance in social enterprise. Voluntas International Journal of 
Voluntary \& Nonprofit Organizations, Aug. 2016, 27(4), 1742-1759.

Plotnieks, D. (2014). Mechanisms fostering social entrepreneurship as potential instruments for economic development: The Eastern Partnership Perspective. Baltic Journal of European Studies, 4(2), 34-49. https://doi.org/10.2478/bjes-2014-0014

Pomykol, A., Zglinicka, K, \& Masłowski, P. (2016). Recommendation for public administration on municipality level in terms of effective tools stimulating development of social economy start-ups.

Pukis, M. (2012). Sociālās uznēemējdarbības attīstības iespējas Latvijā [Social entrepreneurship development opportunities in Latvia]. Retrieved from http://www. biznesa-attistiba.lv/index.php?lng= $1 \mathrm{v} \& \mathrm{id}=21$

Raišiene, A. G., \& Urmanavičiene, A. (2017). Mission drift in a hybrid organization: How can social business combine its dual goals?. Ekonomski Vjesnik/ Econviews, 30(2), 301-310.

Russell, M. (2002). What disability civil rights cannot do: Employment and political economy. Disability and Society, 17(2), 117-137.

https://doi.org/10.1080/09687590120122288

Saeima (Parliament of Latvia). (2015). Brīvprātīgā darba likums [The Law on Voluntary Work]. Latvijas Vēstnesis, 02.07.2015, Nr 127(5445).

Saeima (Parliament of Latvia) (2016). Publisko iepirkumu likums [Public Procurement Law]. Latvijas Vēstnesis, 29.12.2016, Nr 254 (5826).

Saeima (Parliament of Latvia). (2003). Biedrību un nodibinājumu likums [Associations and Foundatins Law), Latvijas Vēstnesis, 14.11.2003, Nr.161(2926).

Saeima (Parliament of Latvia). (2004). Sabiedriskā labuma organizāciju likums [Public Benefit Organisation Law]. Latvijas Véstnesis, 07.07.2004, Nr. 106 (3054).

Saeima (Parliament of Latvia). (2017). Sociālā uzṇēmuma likums [Social Enterprise Law]. Latvijas Vēstnesis, 25.10.2017, Nr. 212 (6039).

Salamon, L. M., \& Sokolowski, S. W. (2016). Beyond nonprofits: Re conceptualizing the third sector, Voluntas. International Journal of Voluntary \& Nonprofit Organizations, 27(June), 1515-1545.

https://doi.org/10.1007/s11266-016-9726-Z
Salamon, L. M., Sokolowski, W., \& Associates. (2004). Global civil society: Dimensions of the nonprofit sector. Vol. 2. USA, Bloomfield, CT: Kumarian Press.

Salamon, L., Anheier, H, K., List, R., Toepler, S., Sokolowski, S. W. \& Associates. (1999). Global civil society: Dimensions of the nonprofit sector. USA, Baltimor, The Johns Hopkins Center for Civil Society Studies.

Shina, I., \& Titko, J. (2017). Social Entrepreneurship Development Factors in Europe. In: In : Proceedings of the 2017 International Conference "Economic Science For Rural Development” No 46 Jelgava, LLU ESAF, 27-28 April 2017, pp. 158-165.

Social Entrepreneurship Association of Latvia (SEAL). (2017). Social entrepreneurship in Latvia: 19 success stories. Retrieved from https://www.socialauznemejdarbiba.lv/eng/

Social Entreprenurship Association of Latvia (SEAL). Information in web page. Retrieved from https://www.socialauznemejdarbiba.lv/eng/

Szegedi, K, Gyula Fülö, G., \& Ádám Bereczk, A. (2016). Relationships Between Social Entrepreneurship, CSR and Social Innovation: in Theory and Practice. International Journal of Social, Behavioral, Educational, Economic, Business and Industrial Engineering, 10(5), 1402-1407.

Ventspils pilsētas Dome (Ventspils City Council). (2013). Ventspils pilsētas attīstības programmas 2014-2020 gadam [Venstpils City Development Programm 20142020]. Retrieved from http://www.ventspils. lv/lat/

Ventspils pilsētas Dome (Ventspils City Council). (2016). Ventspils pilsētas attīstības programmas 20142020.gadam rīcības plāns [Action Plan of the Ventspils City Development Program for 2014-2020]. Retrieved from http://www.ventspils.lv/lat/

Ventspils University College. (2017). Reasons for the unemployment of Ventspils city and county residents and proposals for improving the situation. (Unpublished, property of Ventspils City Council).

Yunus, M. (2006). Social business entrepreneurs are the solution. In A. Nicholls (Ed.), Social Entrepreneurship: New models of sustainable social change (Chap. 1., pp. 39-44). Oxford: Oxford University Press. 